The BDJ News section accepts items that include general news, latest research and diary events that interest our readers. Press releases or articles may be edited, and should include a colour photograph if possible. Please direct your correspondence to the News Editor, Arveen Bajaj at the BDJ, 64 Wimpole Street WIG 8YS or by email to bdj@bda.org

\section{Plans for complaints scheme in place}

The General Dental Council is pushing forward plans to get its scheme for non-NHS dentistry complaints up and running as soon as possible, it claims.

According to the Council, a key feature will be a telephone service, providing information to anyone with a dental complaint. Those whose complaints relate to NHS dentistry will be referred to the appropriate NHS authority. For complaints about non-NHS dentistry, the scheme will help patients and dental professionals to resolve complaints swiftly and informally.

Legislation needed to implement the GDC's reform programme was granted by the Government recently and will be in place by January 2005

\section{New visiting Professor appointed}

Professor James Roelofse has been appointed visiting Professor at the Eastman Dental Institute. He will be developing conscious sedation courses for medical and dental practitioners within Eastman CPD.

He is Professor and Head of Anaesthesiology and Sedation at the University of the Western Cape in South Africa and was previously Professor and Consultant Anaesthesiologist at the University of Stellenbosch. Professor Roelofse has lectured internationally on conscious sedation and has a special interest in paediatric sedation.

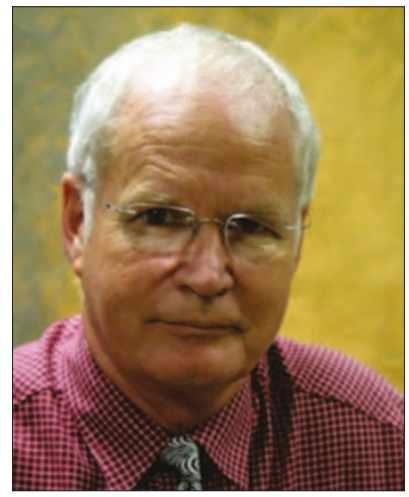

\title{
Racing ace supports campaign
}

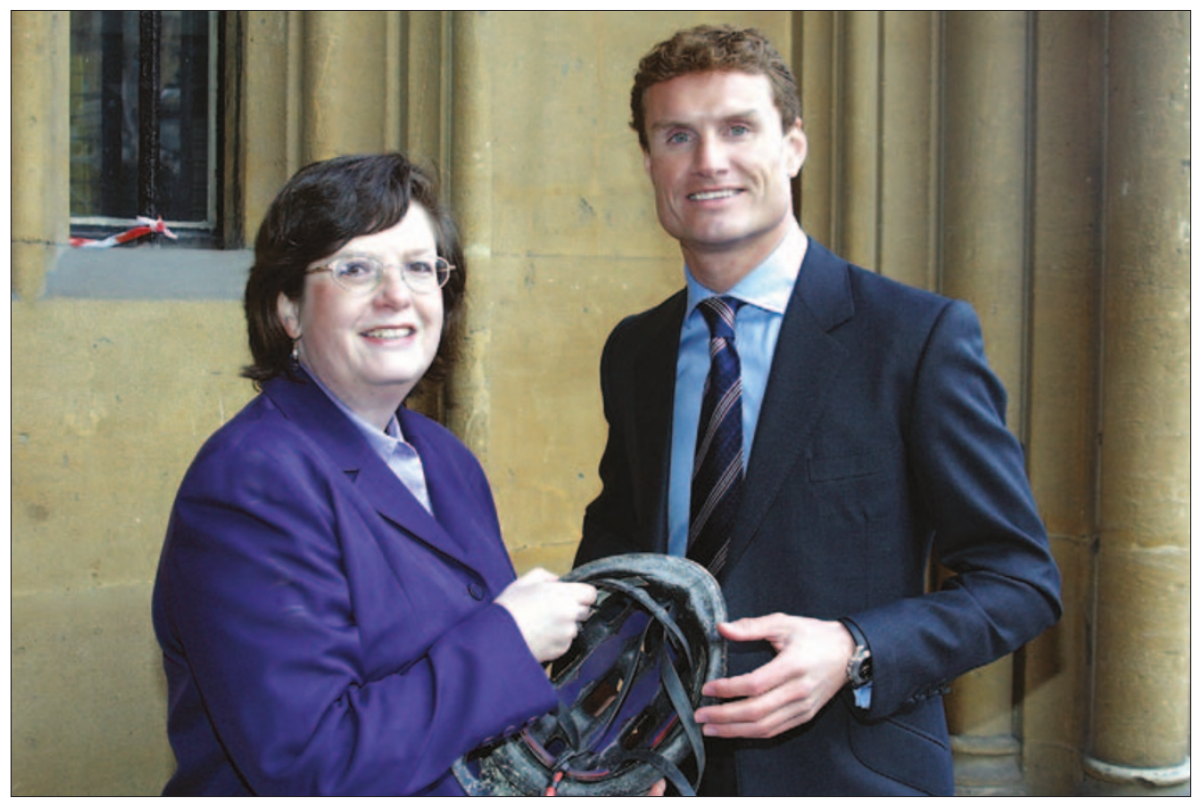

Registered Specialist in Paediatric Dentistry Helen Chapman (above left) has campaigned vigorously to bring about more awareness for the need for head protection to help reduce the impact of injuries to the head/face which can cause serious facial and dental injuries to children. The 'Protective Head Gear for Young Cyclist Bill' will be getting its second reading on 23 April. Formula 1 racing star David Coulthard (above right) lent his support to the campaign at the launch of the Private Members Bill at the Palace of Westminster last month.

\section{Radiation protection guidelines issued}

The European Commission has just published the document: Radiation Protection 136: European Guidelines on Radiation Protection in Dental Radiology. The evidence-based guidelines were produced by a working party coordinated from Manchester Dental School under the chairmanship of Professor Keith Horner and included contributors from Leeds, Amsterdam and Athens.

The aim of the study was to provide a practical guide to radiation protection for professional groups of dentists and their assistants, based upon the two relevant council directives of the European Union. These are laying down of the basic safety standards for the protection of the health of workers and the general public against the dangers arising from ionising radiation, and on health protection of individuals against the dangers of ionising radiation in relation to medical exposure. It is hoped that the guidelines will contribute to optimising the use of ionising radiation in dentistry. The document is available on the internet as a pdf file at http://europa.eu.int/comm/energy/nuclear/radioprotection/publication en.htm.

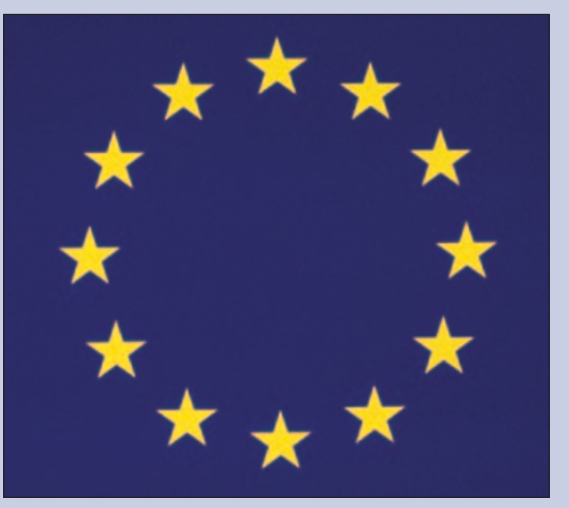




\section{DIARY}

May 2004

British Dental Conference and Exhibition Date: 06-08.05.04

Contact: Delegate Management Services Venue: Bournemouth International Centre (BIC)

Tel: 08701666625 or + 44 (0) 1252

771425 (from overseas)

Fax: 08705228890 or + 44 (0) 1252

771790 (from overseas)

www.bda-events.org

Teaching Challenges for Changing Times Date: 11.05.04

Venue: University of Liverpool Contact: Dr Lesley Longman

Tel: +44 (0) 1517065110

Fax: +44 (0) 1517065807

Email:Iplong@liverpool.ac.uk

Defence Dental Agency Clinical Day

Date: 21.05.04

Venue: JSCSC Officers' Mess,

Shrivenham

Contact: Captain Paul Leighton

Tel: +44 (0) 1296656407

Email: dda-ppcc@defence.mod.uk

Clinical Innovations Conference

Date: 28-29.05.04

Venue: Royal College of Surgeons

Contact: Lisa Casey

Tel: +44 (0) 78436861

Email: lisa@smile-on.com

www.clinicalinnovations.co.uk

\section{Researchers recognised at IADR}

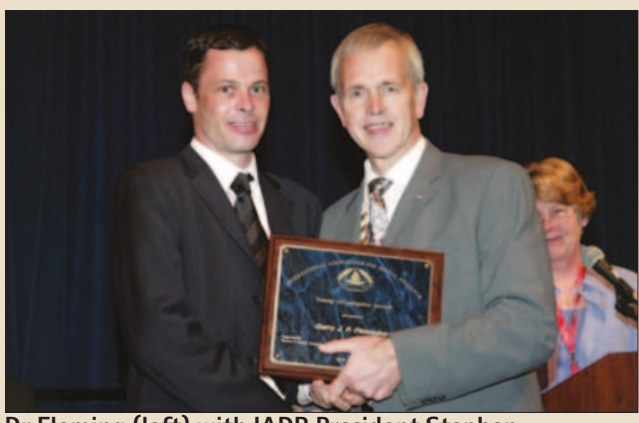

Dr Fleming (left) with IADR President Stephen Challacombe

influence of clinically induced variables in dental luting cements and alternatives to amalgam alloys. Nadia Al-Hazmi was awarded the IADR/Colgate Research in Prevention Travel award which enables young investigators presenting original research in the area of oral disease prevention to travel to the IADR general session.

Harprit Jandu, Julia McClachlan and Paula Smith from the UK and Justin Barnes and Rory Maguire from Ireland were all awarded the IADR/Unilever Division Travel award. The award was established to encourage outstanding young dental scientists to carry out research, attend the IADR general session and to compete in the IADR/Unilever Hatton Awards competition.

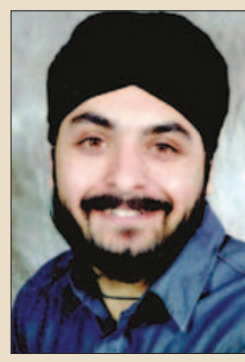

Harprit Jandu
A number of individuals from the UK and Ireland were recognised at this year's International Association for Dental Research (IADR) Annual Meeting in Hawaii.

Dr Garry James Patrick Fleming was awarded the 2004 Young Investor Award which is designed to stimulate basic research in all dental disciplines. Dr Fleming's research focuses on dental biomaterials including the

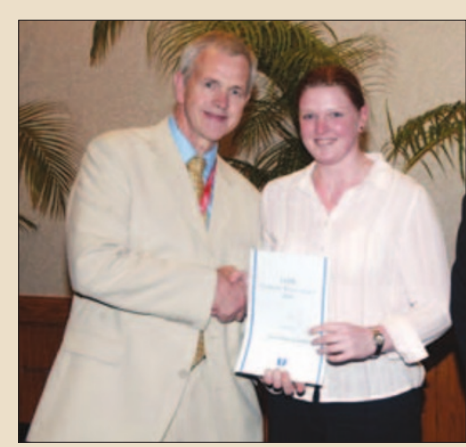

Stephen Challacombe (left) and Julia McClachlan

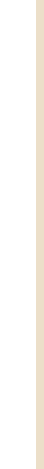




\section{Police request dentists' help over unidentified body}

Thames Valley Police are requesting the help of dentists to identify a body found in woodland in December last year in Reading, Berkshire.

The individual had been dead for several months, and all efforts to date by both the police and the coroner's office have not resolved the issue of who this person is.

Established to date is that he was a male, his hair was black and quite long, possibly in a pony tail. He had a gold stud earring in his left ear and was approximately six feet tall.

One distinguishing feature was that he had what is known as a foot drop splint on his right foot/leg.

Enquiries in relation to this have not helped to identify him though the police have been informed that with this type of splint he would either have walked with a limp or at least dragged his foot. He was believed to be around 40 years-of-age but a plus or minus of ten years must be considered.

Several of the fillings, especially those inserted in UR6 (labelled '1' in dental chart below) were probably inserted recently and LL7 has been root filled.

Anyone who has information which could help identify the individual should contact P.C. Paul Beecroft, (P.C. 2386) on telephone number 01189536153 , or by email at Paul.Beecroft@thames valley.pnn.police.uk.
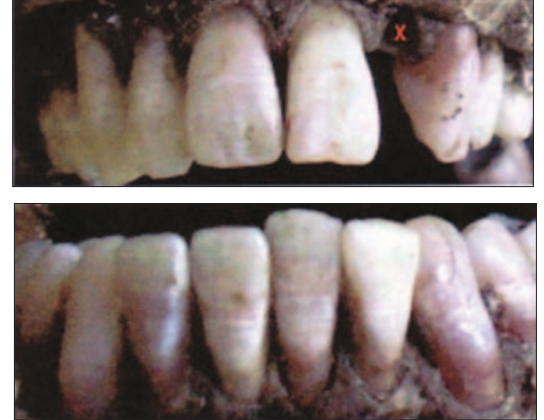

'X' = UL2 missing following post mortem

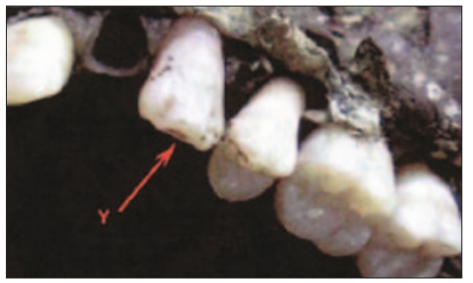

Photograph demonstrating incisal tooth wear on UL3

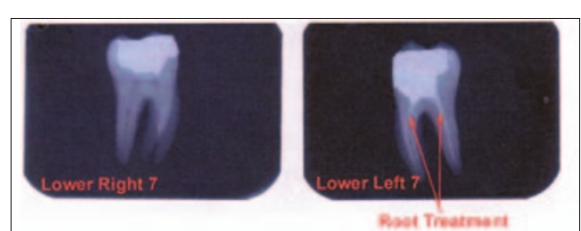

The two lower second molars showing the extent of the amalgams. Lower left 7 has been root filled

\section{valley.pnn.police.uk.}

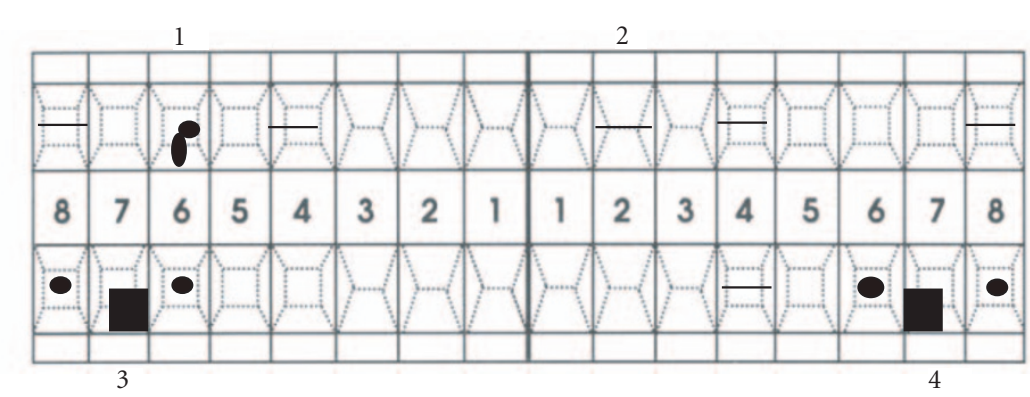

Dental Chart. 1. Recent amalgam filling 2. Upper left lateral incisor lost post mortem (removed by hospital pathologist) 3. Heavily restored lower right second molar (LR7) 4. Heavily restored lower left second molar (LL7)

\section{Dentaid to hold fundraising evening}

Specialist dental charity Dentaid is holding a fundraising dinner to raise funds for its new partner projects, and to give its supporters a chance to hear about future developments at the charity. Prevention and volunteer placement programmes will soon complement Dentaid's equipment refur-

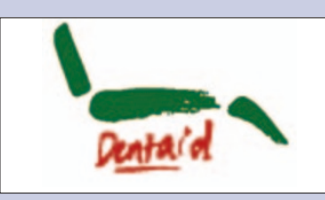
bishment operation, and Bridge2Aid, Dentaid's partner in Tanzania with whom the volunteer placement programme will be piloted this year, will co-host the event. It will take place on 6 May in Bournemouth and coincides with the BDA Conference and Exhibition. For further details contact 01794324249 or email info@dentaid.org. 